\title{
Pustular dermatosis caused by fire ant (Solenopsis invicta) stings in a dog
}

\author{
Lissandro G. Conceição*, Vidal Haddad Jrt and \\ Fabricia Hallack Loures*
}

* Departamento de Veterinária, Universidade Federal de Viçosa, Viçosa, Minas Gerais, Brazil

†Departamento de Dermatologia e Radioterapia, Faculdade de Medicina, Universidade Estadual Paulista, Botucatu, São Paulo, Brazil Correspondence: Lissandro G. Conceição, Departamento de Veterinária, Universidade Federal de Viçosa, Viçosa, MG, 36570-000, Brazil. E-mail: lissandro@ufv.br

What is known about the topic of this paper

- Prior study of experimental fire ant stings revealed vascular congestion, oedema, dermal necrosis and inflammation.

What this paper adds to the field of veterinary dermatology

- Accidental fire ant stings in a dog caused pustular skin lesions.

- The lesions were similar to the lesions of human beings stung by fire ants.

- An area of dermal collagen degeneration plus intra epidermal neutrophilic pustule and dermal neutrophilic inflammation is suggestive of fire ant sting in the dog.

\begin{abstract}
This paper reports a case of spontaneous fire ant sting dermatitis in canine. The skin lesions consisted of nonfollicular, grouped pustules in the abdominal region. Several fire ants were found attached to the lesional skin. Histopathological findings included an intraepidermal neutrophilic pustule and predominantly neutrophilic interstitial dermatitis. An extensive area of collagen degeneration was also observed below the epidermal pustule. These clinical and histopathological findings are remarkable similar to those observed in fire ant stings in humans.
\end{abstract}

Accepted 28 September 2006

\section{Introduction}

Ants are insects belonging to the order Hymenoptera and superfamily Formicoidea that exhibit a complex social structure. There are many families and genera of ants around the world, but only a few species cause injuries with important repercussions in humans. The Solenopsis spp. are of the most important medical interest. Two species are found in Brazil: Solenopsis invicta, known as red fire ants, originally from the Pantanal (the Brazilian swampland, located in the mid-west region of the country).

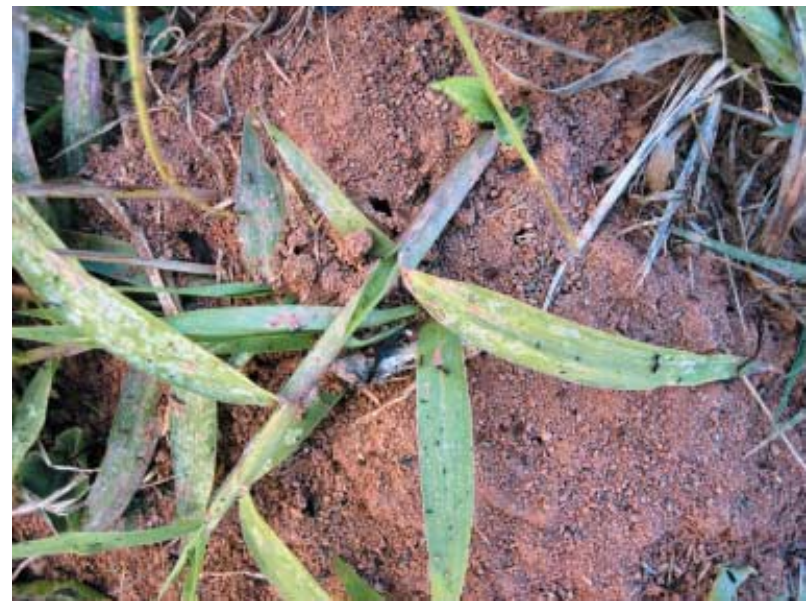

Figure 1. Fire ant anthill. After a mechanical insult, several fire ants leave the anthill.

These ants have been disseminated to other countries, including the USA, where they are actually considered a Public Health problem. The second species is Solenopsis richteri, originally from Rio Grande do Sul State, as well as other South American countries such as Argentina and Uruguay. ${ }^{1}$

These ants, popularly known in Brazil as formiga lavapés and, in the USA, as imported fire ants, live in anthills with several exit holes (Fig. 1). When the anthill is disturbed, hundreds of ants aggressively attack the intruder and each ant can sting up to 10 times. After being in contact with an anthill, the victim may suffer from hundreds of stings. The ants fix to the skin with their jaws and sting using a specialized apparatus in the abdomen, which is connected to venom glands. ${ }^{2,3}$ In sensitive individuals, the sting can lead to allergic manifestations similar to the anaphylactic reactions caused by bees. The presence of bacterial infection is not uncommon. ${ }^{2}$ Injuries in humans occur mainly in children, alcoholics and individuals with locomotor deficits. ${ }^{2}$ The clinical differential diagnosis includes subcorneal pustular dermatosis, pustular psoriasis and other skin diseases manifested by pustules. However, the patient history assists diagnosis. Treatment usually includes antihistamines and topical corticosteroids and antibiotics. ${ }^{2}$

The stings of $S$. invicta cause typical and well-described cutaneous lesions in humans. In the initial moments, each sting causes a highly pruritic urticariform papule. Within $24 \mathrm{~h}$, the papule progresses to a sterile pustule (Fig. 2). The purpose of this article is to report a natural case of skin lesions caused by $S$. invicta stings in a dog.

\section{Case report}

A young adult intact mongrel bitch was presented for routine veterinary care. The physical examination revealed 


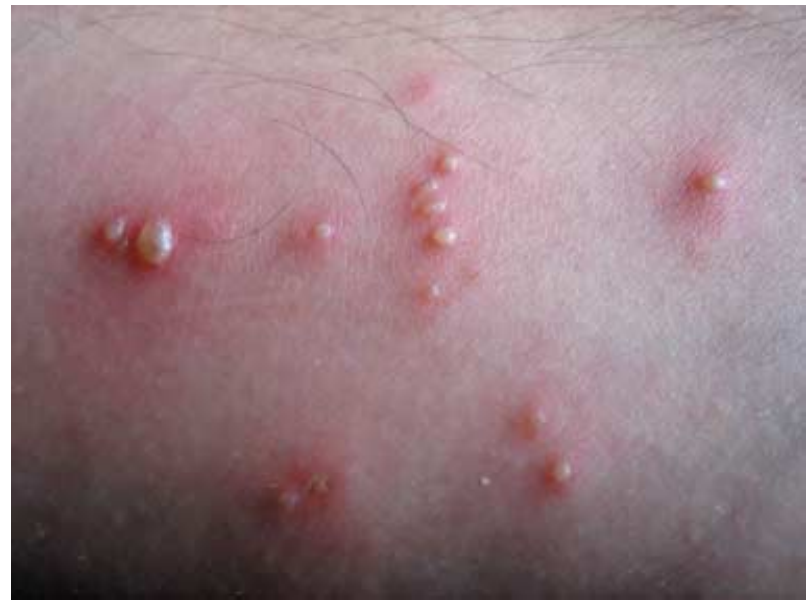

Figure 2. Posterior aspect of the arm of one of the authors (LGC) subjected to an experimental fire ant sting. Note the pustules and erythema $24 \mathrm{~h}$ after the sting.

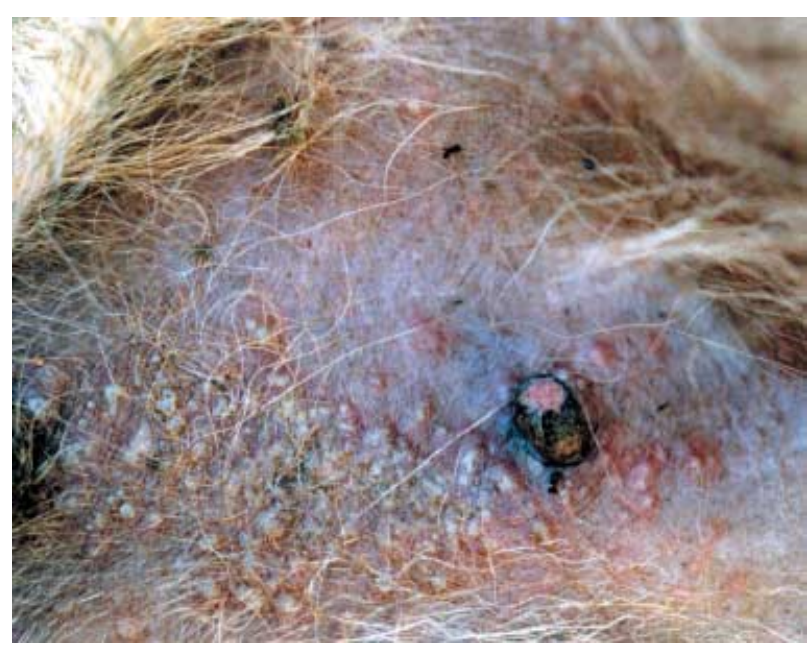

Figure 3. Abdominal region of the dog stung by fire ants. Several grouped yellow nonfollicular pustules and several fire ants attached to the skin.

skin lesions in an otherwise healthy dog. Several grouped, nonfollicular, circumscribed yellow pustules were present on the ventral abdominal and inguinal areas (Fig. 3). On close observation, the pustules were relatively tense, surrounded by a slight erythematous halo, and several dead fire ants were attached to the skin and hairs. Pruritus, pain or discomfort was noted neither during physical examination nor by the owner. There was no history of previous drug administration. The differential diagnoses were pustular dermatitis caused by fire ant stings, impetigo, superficial bacterial folliculitis, dermatophytosis, demodicosis, subcorneal pustular dermatitis, and pemphigus foliaceous.

Skin scrapings and fungal cultures (Sabouraud's dextrose agar) were negative for mites and dermatophytes, respectively. Cytological examination of an intact pustule revealed both degenerate and nondegenerate neutrophils but without bacteria or acantholytic cells. Two punch skin biopsies were taken from pustular skin lesions and the dog was sent home. In order to control possible pruritus or discomfort, an oral antihistamine (hydroxyzine $-2.2 \mathrm{mg} \mathrm{kg}^{-1}$ three times a day) was dispensed for administration by the owner.

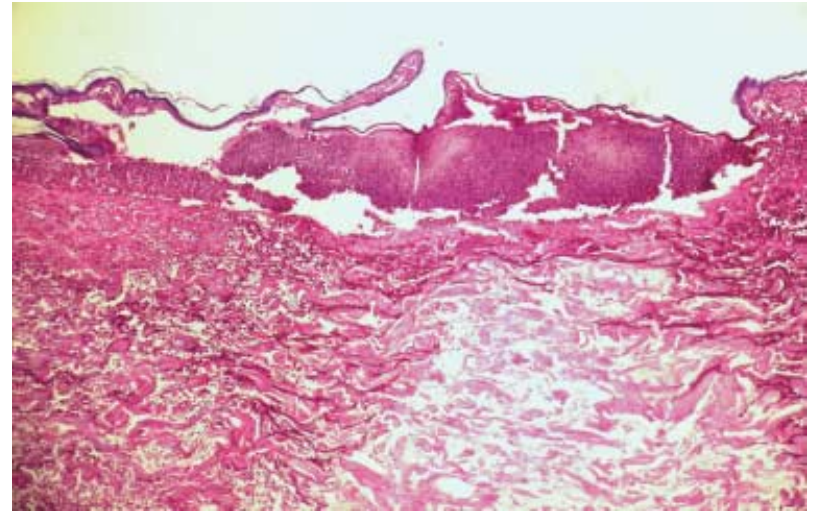

Figure 4. Histopathology of canine fire sting. Intraepidermal neutrophilic pustule and interstitial neutrophilic dermatitis ( $\times 40-$ haematoxylin and eosin). Note the area of collagen degeneration.

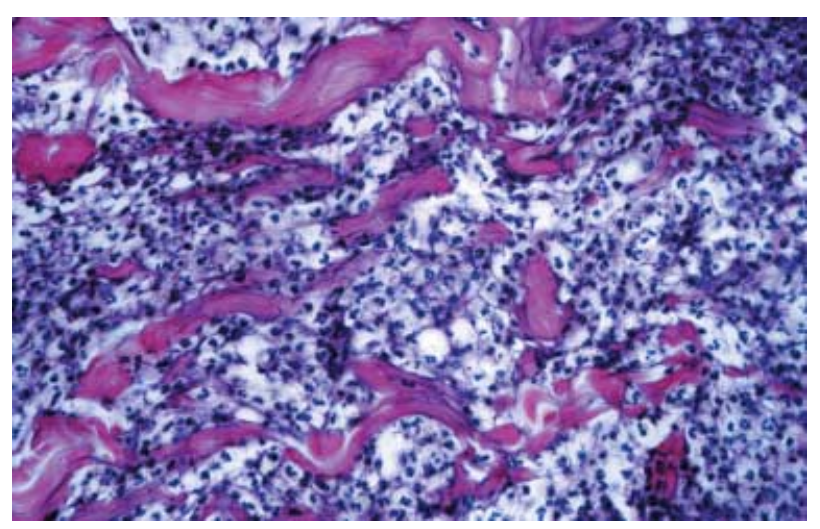

Figure 5. Histopathologyof canine fire sting. Closer view of the dermal interstitial neutrophilic inflammation. ( $\times 400-$ haematoxylin and eosin).

Histopathological examination of an intact pustule revealed an intraepidermal pustule, and dense superficial and deep dermal interstitial neutrophilic dermatitis, which extended to the panniculus (Figs 4 and 5). Collagen degeneration, vascular congestion and oedema were also observed. Below the neutrophilic pustule there was a large area of hyaline collagen degeneration with sparse cellular debris. The clinical and histopathological findings were diagnostic for fire ant sting dermatitis. Several months later the owner reported that the oral antihistamine was not given but the dog had an uneventful resolution of skin lesions within a few days.

\section{Discussion}

To our knowledge this is the first report of non-experimental fire ant sting skin lesions in canine.

In humans, the venom of the $S$. invicta provokes local inflammation characterized initially by urticariform papules. These lesions progress to vesicles and sterile pustules within $24 \mathrm{~h}$. The substance implicated in the pathogenesis is the trans-2-methyl-6-n-undecylpiperidine (Solenopsin-A), an alkaloid piperidine derivate. This chemical, which is the first identified animal venom of an alkylated piperidine origin, possesses cytotoxic effects, is chemotactic for neutrophils, and can cause skin necrosis. ${ }^{1-3}$ 
Textbook photographs of fire ant stings on a dog's muzzle show pustules and vesicles with a distinct white colour. ${ }^{4}$ In contrast, in the case described here, the pustules had a more yellowish colour and no vesicles were noted. These differences could be explained by differences in the stage of lesion evolution.

There is a single previous report of experimental fire ant stings in canine. Six hours after the stings, the dogs developed pruritic and erythematous papules that gradually faded in the following $72 \mathrm{~h}$. Microscopically, early vascular congestion and superficial dermal oedema progressed to full thickness dermal necrosis and inflammation. ${ }^{5}$

The gross and microscopic findings of this case differ from this experimental report. Pustular skin lesion and an intraepidermal pustular dermatitis plus dermal collagen degeneration and interstitial neutrophilic dermatitis were the main histopathological findings. The clusters of pustules on the abdomen are probably the result of an attack when the dog lay down on an anthill. The relatively glabrous abdominal skin may have facilitated the access of the fire ants to the skin. The clinical and histopathological appearance are similar to that described in humans. ${ }^{1-3}$ The differential diagnoses in veterinary patients include other pustular skin diseases such as impetigo, superficial pemphigus and subcorneal pustular dermatosis. In the case described here, the presence of several fire ants attached to the skin was considered diagnostic. However, when fire ants cannot be found on the animal, the dermal changes (i.e. dense superficial and deep interstitial neutrophilic dermatitis with central collagen degeneration) allow histological differentiation from impetigo, subcorneal pustular dermatosis and pustular drug eruption. These other dermatoses exhibit a more superficial and mild dermatitis., 4 A similar area of noncellular collagen degeneration was observed on biopsy of an experimental fire ant sting in the arm of the one of the authors ( $\mathrm{VHJ}$ ) for scientific purpose.
Most cases of fire ant stings in humans are probably not seen by a medical service and resolve without treatment. We believe that the same is true for veterinary medicine because exposure of dogs to fire ants is very common in Brazil. In the case presented here, despite the multiple pustular lesions the dog did not show any pain or pruritus and recovered without treatment in a few days.

In humans the sting is painful and becomes pruritic in a few hours. Abscesses, cellulitis and erysipelas can develop at the affected site as a result of self-inflicted trauma. ${ }^{1}$ In rare instances, severe allergic reactions can result in death. Fire ant stings could cause anaphylactic shock in veterinary patients as well, although this has not yet been reported.

Based on the case presented here, in fire ant endemic areas, fire ant sting dermatitis should be included in the list of possible diagnoses in cases of canine sterile neutrophilic intraepidermal pustular dermatitis.

\section{References}

1. Haddad Jr V. Acidentes por formigas. In: Manual de Diagnóstico e Tratamento de Acidentes por Animais Peçonhentos. Brasília, Brazil: Fundação Nacional de Saúde, 1999: 26-30.

2. Haddad Jr V, Cardoso JLC, França FOS et al. Acidentes provocados por formigas: um problema dermatológico. Anais Brasileiros de Dermatologia 1996; 71: 527-30.

3. Haddad Jr V, Cardoso JLC, Wen FH et al. Animais Peçonhentos no Brasil. 1. ed. São Paulo, Brazil: Sarvier Editora de Livros Médicos Ltda, 2003.

4. Gross TL, Walder EJ, Ihrke PJ. Skin Diseases of the Dog and Cat. Clinical and Histopathologic Diagnosis, 2nd edn. Oxford, UK: Blackwell Publishing, 2005: 932.

5. Rakich PM, Latimer KS, Mispagel ME et al. Clinical and histologic characterization of cutaneous reactions to stings of the imported fire ant (Solenopsis invicta) in dogs. Veterinary Pathology 1993; 30: 555-9.

6. Scott DW, Miller WH, Griffin CE. In: Muller and Kirk's Small Animal Dermatology, 6th edn. Philadelphia, PA: WB Saunders, 2001: 1528.

Résumé Cet article rapporte un cas de dermatite due aux fourmis chez le chien. Les lésions cutanées consistaient en des pustules non folliculaires regroupées dans la région abdominale. Plusieurs fourmis ont été observées attachées à la peau sur les zones lésées. L'examen histopathologique montrait des pustules neutrophiliques intraépidermiques et une dermatite interstitielle neutrophilique. Une zone de dégénérescence collagénique était observée sous la pustule épidermique. Ces observations cliniques et histopathologiques sont remarquablement semblables à celles observées chez l'homme.

Resumen En este artículo describimos un caso de dermatitis espontánea producida por la mordedura de hormigas sudamericanas del fuego. Las lesiones de la piel consistieron en grupos de pústulas no foliculares en la región abdominal. Varias hormigas se encontraron adheridas a la zona de las lesiones. En análisis histopatológico se observaron pústulas intraepidermales de neutrófilos y sobre todo dermatitis neutrofílica intersticial. Un área extensa de degeneración del colágeno se observaba debajo de las pústulas epidermales. Estos hallazgos clínicos e histopatológicos son similares a los observados en personas con mordeduras producidas por el mismo tipo de hormigas.

Zusammenfassung Diese Veröffentlichung berichtet über einen Fall von spontaner caniner Dermatitis durch einen Feuerameisenbiss. Die Hautläsionen bestanden aus nicht-follikulären Pusteln, die in Gruppen in der Abdominalregion vorkamen. Mehrere Feuerameisen wurden an der läsionalen Haut hängend, gefunden. Die histopathologischen Befunde bestanden aus intraepidermalen neutrophilen Pusteln und einer hauptsächlich neutrophilen interstitiellen Dermatitis. Außerdem bestand eine großflächige Ausbreitung von kollagener Degeneration unterhalb der epidermalen Pustel. Diese klinischen und histopathologischen Befunde waren jenen auffallend ähnlich, die bei menschlichen Feuerameisenbissen beobachtet werden. 